\title{
Dinamika Pendidikan Tinggi Vokasi Penerbangan Merespon Isu Industri 4.0
}

\author{
Benny Kurnianto \\ DOI: https://doi.org/10.36339/jaspt.v3i2.261
}

\begin{abstract}
Discussing about human development, the topic that keeps exist in higher education is skill-gap between university and industry. The challenge is getting harder with shifting condition in the globe including the issue of industrial revolution 4.0. This challenge has immediate effect on the existence and the development of vocational academy such as Indonesian Civil Aviation Institute. Therefore, this study explores the changes that occur in as Indonesian Civil Aviation Institute as a result of higher education policy in Indonesia. This study use SWOT analysis to examine the strategies taken by this university to encounter the issue. According to this research, there are dynamic changes in the relation between this university, government, and industry as the outcome of dissimilar interpretation of the issue.
\end{abstract}

Keywords: industry 4.0, skill gap, mismatch

\begin{abstract}
Abstrak
Permasalahan yang selalu muncul dalam dunia pendidikan tinggi di Indonesia adalah ketidakselarasan hubungan antara industri dan pendidikan tinggi. Tantangan bertambah rumit dengan perubahan situasi global termasuk di dalamnya isu revolusi industri 4.0. Tantangan dan isu tersebut berdampak langsung terhadap keberadaan dan keberlangsungan pendidikan vokasi penerbangan. Oleh karena itu, studi ini akan mendiskripsikan dinamika yang terjadi di Sekolah Tinggi Penerbangan Indonesia sebagai dampak perubahan tata kelola pendidikan tinggi di Indonesia akibat isu tersebut. Analisa dilakukan berdasar pada kekuatan, kelemahan, peluang, dan ancaman terhadap strategi yang diambil organisasi dalam menghadapi tantangan isu industri 4.0. Studi ini menemukan bahwa strategi yang diambil berdampak pada terjadinya perubahan relasi antara perguruan tinggi vokasi ini dengan pihak regulator dan industri yang diakibatkan variasi penerjemahan terhadap isu yang berkembang.
\end{abstract}

Kata Kunci: vokasi, industri 4.0, link and match

\section{PENDAHULUAN}

Link and match, --sebuah kebijakan yang dikembangkan Mendikbud Wardiman Joyonegoro pada tahun 1990-an yang ditujukan untuk meningkatkan relevansi pendidikan vokasi dengan kebutuhan dunia kerja, dunia usaha serta dunia industri

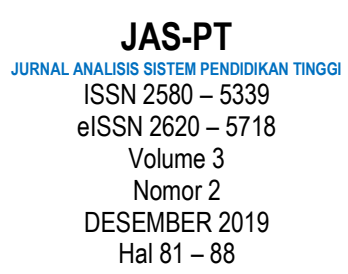

FORUM DOSEN INDONESIA
Politeknik Penerbangan Indonesia Curug - Indonesia

EMail

bennykurnianto@yahoo.com

Submitted:

Oktober 2019

Accepted : December 2019 
khususnya,-- menjadi topik diskusi yang tidak pernah usang dalam membahas sumber daya manusia dan ketenagakerjaan. Hal ini mengindikasikan bahwa sulitnya lulusan perguruan tinggi untuk masuk dunia kerja dinilai karena adanya ketidakselarasan antara kebutuhan di dunia industri dengan penyediaan di dunia pendidikan. Beberapa ahli bahkan menggunakan istilah skill mismatch atau skill gap untuk memberikan penekanan pada perbedaan atau kesenjangan antara kompetensi yang diajarkan di sekolah dengan skill yang harus dikuasai untuk masuk ke dunia industri.

Senarath dan Patabendige (2014) yang dikutip Disas (2018) menjelaskan bahwa pihak industri menyimpulkan bahwa mismatch dan skill gap terjadi karena permasalahan struktur, substansi, dan kualitas sistem pendidikan. Secara spesifik dapat dikatakan bahwa sistem pendidikan tinggi gagal dalam menyiapkan calon tenaga kerja yang memiliki kompetensi, talenta, dan orientasi terhadap pekerjaan yang dibutuhkan.

Berkaca pada faktor tersebut, para pengambil kebijakan berupaya menekan disparitas dengan mencari formula baru dalam penyelenggaraan pendidikan tinggi terutama pendidikan vokasi. Pendidikan vokasi menjadi sasaran utama dalam implementasi link and match karena jenis pendidikan ini diprioritaskan untuk menyiapkan sumber daya manusia yang langsung dapat diserap dunia industri (Berdasar Nota Kesepahaman (MoU) lima menteri tentang Pengembangan Pendidikan Kejuruan dan Vokasi Berbasis Kompetensi yang Link and Match dengan Industri).

Sekolah Tinggi Penerbangan Indonesia (STPI), sebagai perguruan tinggi vokasi juga menghadapi persoalan skillgap. Pada mulanya seluruh lulusan sekolah ini memiliki ikatan dinas menjadi pegawai di lingkungan Kementerian perhubungan. Namun, setelah era reformasi birokrasi, sistem ikatan dinas dihapus.

Menghadapi fenomena ini, STPI harus menyiapkan peserta didik untuk dapat bersaing baik secara kompetensi maupun legalitas. Kemajuan teknologi informasi dengan isu revolusi industri 4.0 yang diadopsi dunia industri menjadi tantangan baru kampus ini. Langkah strategis diambil untuk meningkatkan daya saing. Dinamika yang terjadi akibat penerapan strategi inilah yang akan dikaji dalam penelitian ini.

Dengan mengeksplorasi startegi dan dinamika yang terjadi, kajian ini diharapkan dapat menjadi dasar evaluasi bagi akademisi maupun para pemegang kebijakan dalam dalam menyikapi isu revolusi indistri 4.0. di dunia industri yang berdampak juga pada dunia pendidikan khususnya pendidikan vokasi penerbangan.

\section{METODE PENELITIAN}

Kajian ini menggunakan metode kualitatif dengan sifat penelitian eksploratif. Observasi dilakukan untuk melihat strategi yang diterapkan. Strategi tersebut kemudian dianalisa untuk mengetahui letak kekuatan, kelemahan, peluang dan tantangannya. Hasil analisa dituliskan secara naratif.

Observasi dilakukan untuk melihat data-data yang berkaitan dengan dosen, mahasiswa, dan lulusan. Selain itu, perlu dilihat juga hubungan yang dibangun organisasi dengan regulator dan industri terkait dengan kemahasiswaan, kedosenan,

JAS-PT

JURNAL ANALISIS SISTEM PENDIDIKAN TING ISSN $2580-5339$ eISSN $2620-5718$

Volume 3

Nomor 2

DESEMBER 2019 Hal $81-88$ dan lulusan.

Kajian ini memanfaatkan analisis SWOT (Strength, Weakness, Opportunities, dan Threat) (USDA, 2008) untuk mendiskripsikan strategi yang diambil organisasi. Analisis dilakukan dengan menggambarkan perubahan hubungan yang tercipta antar pihak yang terkait. 


\section{DISKUSI DAN PEMBAHASAN}

\section{Peran Pendidikan Tinggi}

Etzkowitz \& Leydesdorff pada tahun 1990-an mengembangkan sebuah konsep hubungan antara pendidikan tinggi, pemerintah dan industri dalam pertumbuhan ekonomi. Ketiga aktor ini memiliki peranan utama dalam sistem inovasi. Konsep ini sering digunakan pemerintah sebagai strategi umum yang dikembangkan menjadi kebijakan. Konsep ini juga sudah sering digunakan peneliti/akademisi sebagai kerangka normatif dalam memahami sistem inovasi. Etzkowitz dan Leydesdorff (2000) menekankan bahwa inovasi akan tercipta ketika ketiga aktor; akademisi, industri dan pemerintah mampu menyediakan kondisi yang optimal.

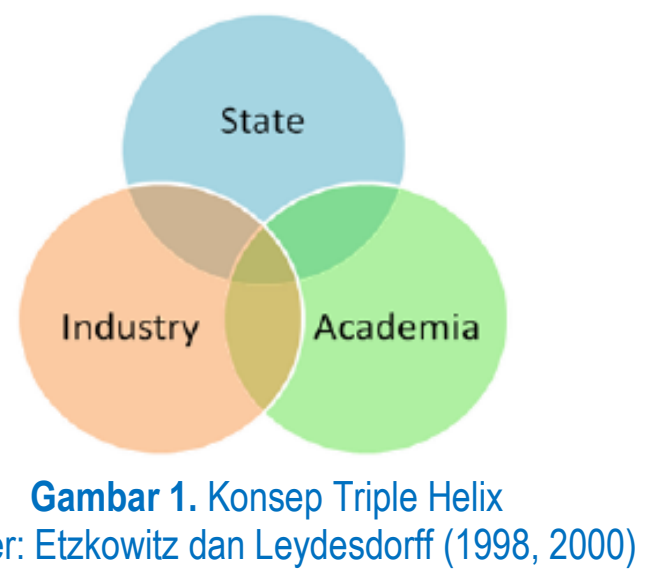

Izzati (2018), mengutip Wishnu dalam APEC CEO Summit 2013 Indonesia, menjelaskan peranan ketiga aktor lebih praktis,

" industri berperan sebagai rumah produksi, sementara pemerintah adalah sumber hubungan kontraktual yang memastikan interaksi dan pertukaran yang stabil, dan universitas sebagai sumber pengetahuan dan teknologi baru.

Melihat konsep ini, peranan pendidikan tinggi dalam menyediakan sumber pengetahuan dan teknologi dapat diimplementasikan dengan beberapa cara. Pertama, akademisi harus mampu menghasilkan kajian ilmiah yang dapat dimanfaatkan industri untuk berinovasi dan digunakan pemerintah untuk menetapkan kebijakan. Kedua, pendidikan tinggi harus mampu menghasilkan lulusan yang memiliki pengetahuan dan cara berfikir (teknologi) yang mampu membuka industri baru ataupun menjadi bagian dari industri yang sudah ada dan berkontribusi dalam menciptakan inovasi.

\section{Tantangan Isu Revolusi Industri 4.0}

Kehadiran Revolusi industri 4.0 memilki ciri adanya pemanfaatan kecerdasan buatan pada bermacam mesin dan alat yang mampu melaksanakan pekerjaan-pekerjaan sederhana (Ayu, 2018).

Di sektor tranportasi udara, baik pemerintah maupun industri terlihat sepakat menyambut dan berusaha memanfaatkan kehadiran industri 4.0. Menteri Perhubungan Budi Karya Sumadi dalam Rapat Kerja Dinas Direktorat Jenderal Perhubungan Udara menyatakan bahwa revolusi industri 4.0 dan pembangunan jaringan transportasi udara yang berkelanjutan berperan penting dalam percepatan pembangunan ekonomi Indonesia. Contoh nyata dari pernyataan ini adalah dukungan pemerintah terhadap industri jasa penerbangan yang melakukan digitilasi pelayanan seperti pemesanan tiket secara daring.

JAS-PT

JURNAL ANALISIS SISTEM PENDIDIKAN TINGGI

ISSN $2580-5339$ eISSN $2620-5718$

Volume 3

Nomor 2

DESEMBER 2019

Hal $81-88$ 
Kondisi ini memiliki konsekuensi munculnya disrupsi jenis pekerjaan tertentu. Sistem otomasi menggantikan tugas yang sebelumya dikerjakan manusia. Artinya, sumber daya manusia yang dibutuhkan industri 4.0 memiliki kompetensi yang berbeda

Bagi dunia pendidikan vokasi penerbangan seperti Sekolah Tinggi Penerbangan Indonesia, fenomena digitalisasi industri membawa pengaruh kuat. Kemampuan digital menjadi tren baru sebagi kualifikasi yang dibutuhkan bisnis berbasis sistem digital.

\section{Persepsi Terhadap Isu Revolusi Industri 4.0}

Isu revolusi industri melanda di hampir semua negara di dunia. Namun, tidak semua pihak mampu mengkalkulasi dampak isu tersebut. UNIDO (The United Nations Industrial Development Organization ) mencemaskan penerapan teknologi modern oleh negara maju akan meningkatkan kesenjangan dengan negara dunia ketiga.

Industri 4.0 merupakan fase lanjutan era digitalisasi di sektor manufaktur, dikendalikan empat disrupsi: peningkatan luar biasa volume data, konektivitas dan kekuatan komputasi, munculnya kemampuan analisis dan kecerdasan bisnis, serta interaksi bentuk baru antara manusia dan mesin dan teknologi augmented reality (Meckinsey, 2015).

Namun, tuntutan era industri baru ini tidak hanya kompetensi menggunakan mesinmesin manufaktur saja, tetapi justru kemampuan menghubungkannya dengan media digital dan cyber. Hal ini menjadi kesempatan lembaga pendidikan ini untuk meningkatkan kapasitas peserta didiknya. Program pendidikan yang semula berorientasi pada penggunaan alat kerja dapat ditingkatkan pada hubungan mesin dan cyber-system. Inti dari industri 4.0 adalah terhubungnya dunia siber dan dunia manufaktur, sehingga tidak lagi membutuhkan kemampuan manusia sebagai operator alat. Langkah ini akan sulit dilakukan apabila peserta didik tidak dibekali kompetensi digital sebagai media cyber physical system.

\section{Strategi}

Isu revolusi industri sebenarnya sudah muncul sejak tahun 2010-an dengan hadirnya internet sebagai media penghubung antara manusia dan mesin (Prasetyo dan Trisyanti, 2018). Di Indonesia sendiri, era digitalisasi sektor transportasi udara diawali dengan hadirnya layanan e-tiketing oleh Garuda Indonesia, Merpati Nusantara dan Airasia di tahun berikutnya.

Sebagai pencetak sumber daya manusia penerbangan, lembaga vokasi penerbangan seperti Sekolah Tinggi Penerbangan Indonesia ikut merasakan dampak tersebut, sebagai contoh materi pelajaran harus mengikuti perkembangan teknologi tersebut. Dengan demikian, perkembangan yang terjadi di dunia industri memaksa kampus penerbangan ini melakukan sejumlah perubahan.

\section{Perubahan Kelembagaan}

Sekolah Tinggi Penerbangan Indonesia pada awalnya merupakan sebuah lembaga pendidikan dan pelatihan yang bertranrsformasi di tahun 2000an menjadi pendidikan tinggi.

JAS-PT

ISSN $2580-5339$ eISSN $2620-5718$

Volume 3

Nomor 2

DESEMBER 2019 Hal $81-88$

Perubahan ini sejatinya membawa dampak positif. Status para pendidik dapat ditingkatkan dari instruktur menjadi dosen. Program pendidikan yang dibuka juga dapat ditingkatkan hingga tingkat Magister.

Namun, proses perubahan kelembagaan ini memiliki kelemahan. Ketentuan menjalankan Tridharma Perguruan Tinggi beserta seluruh aturannya belum sepenuhnya mampu dijalankan setelah hamper 20 tahun berjalan. Hal ini terlihat dari proses audit / akreditasi dari Kemenristekdikti terhadap kampus ini. 
Berpedoman dari catatan tersebut, Sekolah Tinggi Penerbangan Indonesia masih berpeluang untuk meningkatkan reputasi kampusnya dengan meningkatkan kapasitas dosen dan melengkapi syarat penyelenggaraan program studi.

Namun, apabila Sekolah Tinggi Penerbangan Indonesia tidak mampu mengambil kesempatan tersebut, beberapa hal akan mengancam keberlangsungan kampus ini. Tanpa kualifikasi yang mumpuni, dosen tidak akan mampu mengembangkan cara berpikir untuk menciptakan metode dan pendekatan inovatif dalam pengajaran yang berbasis digital. Kemudian, kampus ini harus mampu menarik perhatian generasi milenial, yang dianggap sebagai native-nya era digitalisasi untuk belajar di kampus ini.

\section{Perubahan Pengelolan}

Selain perubahan status kelembagaan yang terjadi di tahun 2000, Sekolah Tinggi Penerbangan Indonesia juga mengalami perubahan pengelolaan yang dimulai tahun 2015. Dalam statunya, Sekolah Tinggi Penerbangan Indonesia dituntut menjadi lembaga yang lebih mandiri dari sisi pengelolaan keuangan dengan menjadi badan layanan umum.

Perubahan ini juga membawa dinamika tersendiri. Dengan pola baru, Sekolah Tinggi Penerbangan Indonesia sejatinya memiliki kewenangan dan peluang dalam memproyeksikan rencana di masa depan dengan prioritas kegiatan akademik yang mendukung peningkatan kemampuan digitalisasi dan pemanfaatan cyber system (salah satu aspek revolusi industri 4.0).

Namun, peluang ini belum dimanfaatkan dengan perencanaan pengembangan sarana dan prasarana utama pengajaran berbasis teknologi informasi.

\section{Perubahan Kurikulum}

Di tahun 2015 Sekolah Tinggi Penerbangan Indonesia mulai menyusun perubahan kurikulum dan setahun kemudian kurikulum baru ini mulai diberlakukan. Perubahan yang paling mencolok dalam kurikulum ini adalah penekanan dari kementerian perhubungan untuk menambah intensitas pembelajaran bahasa penerbangan terutama bahasa inggris dan pengetahuan teknologi informasi.

Kebijakan ini diambil dengan harapan lulusan memiliki daya saing sesuai yang diharapkan badan usaha di sektor perhubungan udara. Di tahun 2018, salah satu BUMN di sektor perhubungan udara, PT Angkasa Pura juga menegaskan bahwa perusahaan tersebut berencana untuk mengelola bandara di luar negeri. Sehingga, kompetensi berbahasa internasional yang standar dan pengetahuan digital menjadi syarat baru bagi lulusan perguruan tinggi yang ingin bergabung di perusahaan ini.

Disahkannya kurikulum yang menekankan kemampuan berbahasa Inggris dan pengetahuan teknologi informasi menjadi peluang besar bagi Sekolah Tinggi Penerbangan Indonesia untuk meningkatkan daya saing. Menciptakan sumber daya manusia yang memiliki pengetahuan digital dan mampu berkomunikasi di dunia internasional menjadi target dari program ini. Namun, jumlah pengajar dan laboratorium sebagai sarana pembelajaran seperti masih menjadi kendala utama.

\section{Relasi dengan Regulator dan Industri}

Hadirnya isu industri 4.0, cara pandang, dan strategi yang diambil terhadap isu tersebut membawa dampak tersendiri terhadap hubungan Sekolah Tinggi Penerbangan Indonesia dengan pihak lain yang berada dalam kerangka sistem inovasi.

Sekolah Tinggi Penerbangan Indonesia merupakan salah satu Unit Pelaksana Teknis Kementerian Perhubungan. Kondisi ini mengakibatkan ada dua wakil pemerintah sebagai regulator yang memiliki relasi kuat terhadap kampus ini yaitu Kementerian

JAS-PT

JURNAL ANALISIS SISTEM PENDIDIKAN TINGG ISSN $2580-5339$ eISSN $2620-5718$ Volume 3 Nomor 2 DESEMBER 2019 Hal $81-88$

FORUM DOSEN INDONESIA 
Perhubungan (Kemenhub) dan Kementerian Risert Teknologi dan Pendidikan Tinggi (Kemenristekdikti).

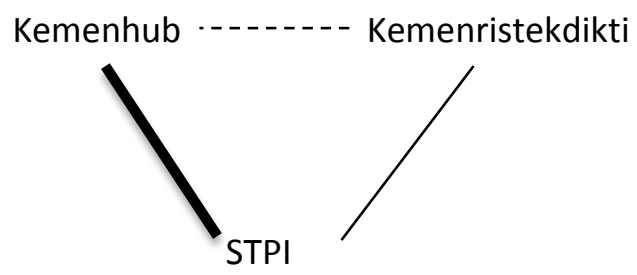

\section{Gambar 2. Relasi dengan Regulator}

llustrasi Gambar 2. diatas menunjukkan hubungan Sekolah Tinggi Penerbangan Indonesia dengan dua regulator yang terjadi sekarang ini. Pada mulanya hubungan hanya terjadi antara Sekolah Tinggi Penerbangan Indonesia dengan Kementerian Perhubungan. Namun, semenjak terjadi perubahan kelembagaan, relasi bertambah kuat antara Sekolah Tinggi Penerbangan Indonesia dengan Kementerian Ristekdikti sebagai pembina penyelenggaraan pendidikan tinggi.

Namun, seperti ilustrasi garis tipis pada gambar, relasi STPI dengan Kemenristekdikti tidak sama dengan kemenhub. Hal ini terlihat dari ketentuan dari kemenhub yang harus dilaksanakan STPI dalam pelaksanaan tridharma perguruan tinggi.

Adanya kebutuhan untuk menjaga keberlangsungan Sekolah Tinggi Penerbangan Indonesia mengakibatkan muncul juga relasi antara Kemenhub dengan Kemenristekdikti. Namun, relasi kedua institusi ini diilustrasikan seperti garis putusputus. Hal ini disebabkan tidak terlihatnya pertemuan yang intens antara kedua pihak ini.

Sedangkan dari sisi akademis, ketentuan yang dikeluarkan kemenhub menjadi beban tersendiri bagi Sekolah Tinggi Penerbangan Indonesia untuk memformulasikannya ke dalam kurikulum program studi sesuai ketentuan kemenristekdikti.

Pihak Kemenristekdikti, yang berulang kali menggaungkan link and match, juga belum mampu memberikan formula yang konsisten sebagai dasar penyelenggaraan pendidikan tinggi vokasi yang mampu menguatkan relasi dengan dunia industri. Program magang industri menjadi langkah yang terlalu umum dalam upaya meningkatkan kualitas lulusan politeknik atau pendidikan tinggi vokasi.

Di sisi lain, Sekolah Tinggi Penerbangan Indonesia juga bertanggung jawab membangun dan menjaga hubungan dengan pihak industri. Seperti dijelaskan di awal, pihak industri sekarang ini menjadi barometer bagi pihak regulator dan pendidikan tinggi mengambil kebijakan.

JAS-PT

JURNAL ANALISIS SISTEM PENDIDIKAN TINGG

ISSN $2580-5339$

eISSN $2620-5718$

Volume 3

Nomor 2

DESEMBER 2019

Hal $81-88$

FORUM DOSEN INDONESIA

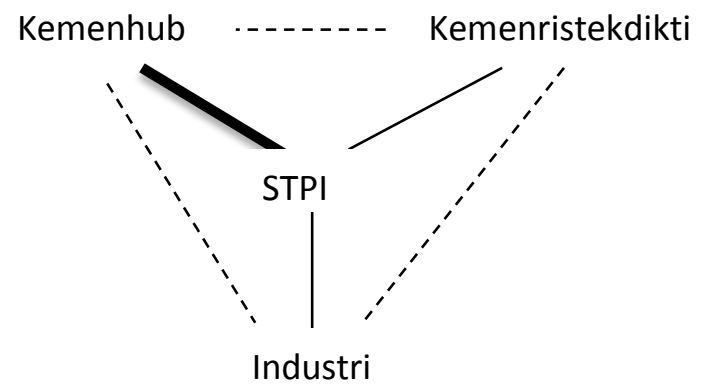

Gambar.3 llustrasi Perluasan Relasi 
Sekolah Tinggi Penerbangan Indonesia sudah menjalin relasi dengan pihak industri penerbangan. Namun, relasi ini memiliki ancaman besar. Tuntutan industri akan sumber daya manusia yang memiliki kemampuan digital dan bahasa asing belum sepenuhnya dipenuhi pihak pendidikan tinggi.

Terlihat sekarang ini perusahaan jasa penerbangan seperti Angkasa Pura yang mempersyaratkan calon pegawai tidak hanya memiliki sertifikat personel atau keahlian penerbangan, tetapi juga menekankan standar kompetensi komunikasi dengan bahasa asing. Kenyataannya, sebagian besar lulusan Sekolah Tinggi Penerbangan Indonesia kesulitan memenuhi syarat ini. Padahal isu ini sudah dikemukakan sejak tahun 2015 bersamaan dengan isu kebutuhan kompetensi teknologi informasi.

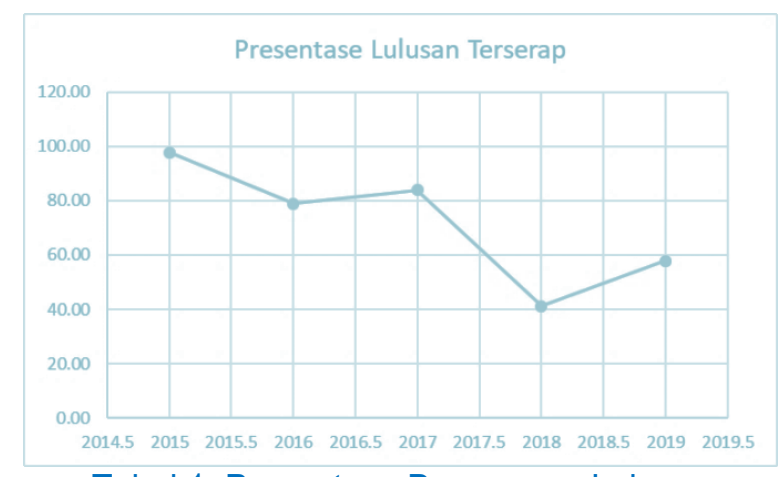

Tabel 1. Presentase Daya serap Lulusan

Tabel 1 diatas memperlihatkan jumlah lulusan yang terserap dalam kurun waktu 20152018 mengalami penurunan dan mulai 2019 daya serap baru mengalami peningkatan.

Strategi Sekolah Tinggi Penerbangan Indonesia yang memperbaharui kurikulum dengan memberi tambahan penekanan pada intensitas pembelajaran bahasa Inggris dan teknologi informasi belum memperlihatkan dampak yang signifikan.

Namun, di sisi lain, tuntutan dunia industri terhadap calon pegawai dari STPI belum mengarah pada kebutuhan teknologi informasi atau pengetahuan digitalisasi.

\section{KESIMPULAN}

Isu Industri 4.0 telah meluas di semua lini, baik pihak industri, pendidikan tinggi maupun pemerintah. Berbeda dengan konsep awalnya di bidang manufaktur, masing-masing pihak memiliki pemahaman sendiri terhadap munculnya isu ini. Dunia pendidikan pun mencoba memformulasikan fenomena ini. Sekolah Tinggi Penerbangan Indonesia sebagai salah satu perguruan tinggi vokasi di bidang penerbangan turut terpengaruh dalam mengambil langkah strategis sebagai respon terhdap isu tersebut.

Berdasarkan analisa kajian ini, strategi-stategi yang diambil membawa dinamika tersendiri. Relasi antara kampus ini dengan industri dan regulator ikut berubah. Isu industri 4.0 memunculkan perbedaan penerjemahan di pihak pendidikan tinggi. Alih-alih mengambil strategi untuk menjawab tantangan industri berbasis digital ataupun cybersystem, langkah-langkah yang diambil justru berbeda dengan konsep link and match. Design pendidikan berbeda dengan penerapan teknologi di pihak industri.

Selain kesimpulan diatas, studi ini mrekomendasikan agar pendidikan tinggi vokasi menerjemahkan isu yang berkembang di industri, seperti link and match dan industri 4.0 sehingga dapat mengambil langkah yang lebih efektif dan efisien untuk menciptakan kondisi yang ideal yang mendukung proses inovasi.

JAS-PT

JURNAL ANALISIS SISTEM PENDIDIKAN TINGGI ISSN $2580-5339$ eISSN $2620-5718$ Volume 3 Nomor 2 DESEMBER 2019 Hal $81-88$ 


\section{DAFTAR PUSTAKA}

Ayu, N.A.K. 2018. Peluang Social Innovation dalam Revolusi Industri 4.0: Bagaimana Perkembangannya di Indonesia. Yogyakarta: Forbil Institute

Disas, E. P. Link and Match sebagai Kebijakan Pendidikan Kejuruan. Jurnal Penelitian Pendidikan, 18(2), 231-242.

Etzkowitz, H., \& Leydesdorff, L. 1995. The Triple Helix - University Industry Government Relations: A Laboratory for Knowledge Based Economic Development. EASST Review 14, 14-19.

Etzkowitz, H., \& Leydesdorff, L. 2000. The Dynamics of Innovation: From National Systems and "Mode 2" to a Triple Helix of University -Industry - Government relations. Research Policy, 29(2), 109-123.

Izzati, MF \& Wilopo. 2018. Implementasi Triple Helix Dalam Mendorong Pertumbuhan Industri Kreatif Di Kota Malang Sebagai Upaya Peningkatan Daya Saing Untuk Menghadapi Masyarakat Ekonomi Asean. Jurnal Administrasi Bisnis (JAB)Vol. 55 No. 1 Februari 2018 hal 59-68.

McKinsey. 2015. Industry 4.0 How to navigate digitization of the manufacturing sector. England: Stamford

Senarath, S. A. C. L., \& Patabendige, S. S. J. (2014). Job-education mismatch among the graduates: A Sri Lankan Perspective. Ruhuna Journal of Management and Finance, 1(2), 1-16.

UNIDO. Industry 4.0: Opportunities and Challenges of the New Industrial Revolution for Developing Countries and Economies in Transition. Panel Discussion

USDA. 2008. SWOT analysis a tool for making better business decisions. United States Department of Agriculture Risk Management Agency.

JAS-PT

JURNAL ANALISIS SISTEM PENDIDIKAN TINGG

ISSN $2580-5339$

eISSN $2620-5718$

Volume 3

Nomor 2

DESEMBER 2019

Hal $81-88$

FORUM DOSEN INDONESIA 